\title{
Effect of Okara flour addition on the physical and sensory quality of wheat bread
}

\begin{abstract}
This study was carried out to develop bread with improved nutritional quality from a soymilk residue, okara, which is considered a foodstuff low-calorie and rich in fiber. Bread was prepared by substituting wheat flour by okara at $5,7.5$ and $10 \%$. Based on preliminary results, breads made with okara improved many nutritional aspects compare with the control (without okara). Okara increased the total dietary fiber and protein content of bread. A darkening was observed in breads with okara regarding the control sample. Control and 5-O samples presented a structure of the crumb with a greater number of air cell than the other formulations, inducing a more uniform distribution of them and a more aerated crumb. From sensory evaluation, it could be concluded that bread with $7.5 \%$ okara presented a great acceptability. Okara represents an excellent raw material that can be utilized for dietary fiber fortification.
\end{abstract}

Volume 4 Issue 6 - 2017

\section{María V Ostermann Porcel, Mercedes E Campderrós, Ana N Rinaldoni \\ Instituto de Investigaciones en Tecnología Química (INTEQUI- CONICET), Facultad de Química,Argentina}

Correspondence: ME Campderrós, Instituto de Investigaciones en Tecnología Química (INTEQUI-CONICET), Facultad de Química, Bioquímica y Farmacia, Universidad Nacional de San Luis, Ejército de los Andes 950- 5700 San LuisArgentina,Tel+54 (266)4520300, Email mcampd@gmail.com

Received: August 31, 2017| Published: September 05, 2017

Keywords: okara, bread, functional food, dietary fibre

and contributes substantially to the intakes of certain nutrients, in the present paper we investigate the optimum level of substitution of okara for wheat flour and examine okara effects on dough texture properties, as well as on quality parameters (volume, hardness and sensory analysis) on the end-product.

\section{Materials and Methods}

\section{Raw materials}

Okara flour was prepared in the laboratory as described by Ostermann Porcel et al. ${ }^{7}$ Wet okara is later dried o $\square$ in a Microwave oven using $40 \%$ power level (BGH, Argentina) in order to reduce the moisture content between $88-90 \%$. Other ingredients wheat flour, yeast, salt, water, fatty matter and sugar were purchased in local market.

\section{Bread making procedure}

Bread was prepared by substituting okara at $0 \%, 5 \%, 7.5 \%$ and $10 \%$ levels into wheat flour. Samples were labelled as: control, $5-\mathrm{O}, 7.5-\mathrm{O}$ and $10-\mathrm{O}$ respectively. The formula contained salt (1\%), yeast $(0.3 \%)$, water $(35 \%)$, fatty matter $(2.4 \%)$ and sugar $(2.7 \%)$. Firstly, yeast was dissolved in water at $37 \pm 1{ }^{\circ} \mathrm{C}$. This dispersion was added to the ingredients and then was mixed with a 5-speed mixer (average mixing speed was 100rpm) (Santini, Argentina) for 30min. Approximately $500 \mathrm{~g}$ of dough was poured into aluminum rectangular moulds $\left(90 \mathrm{~cm}^{2}\right)$. After fermentation (at $30^{\circ} \mathrm{C}$ for $75 \mathrm{~min}$ ), baking was carried out in an air electric oven (BGH, Argentina) at $180^{\circ} \mathrm{C}$ for $40 \mathrm{~min}$ (convection/fan). After baking, the breads were removed from the moulds and cooled at room temperature for $30 \mathrm{~min}$. Samples were packed in hermetically-sealed bags (Ziploc Brand) and stored at ambient temperature.

\section{Physicochemical analysis of bread}

All the methods had previously been applied to characterize the okara flour. ${ }^{8}$ Physicochemical analyses for flour and breads samples ingredient with health-promoting attributes. Considering that wheat bread represents a staple food for the majority of the world population 
were determined in triplicate according to standard replication AOAC methods. ${ }^{9}$ Moisture content was determined by gravimetric method (AOAC 925.10), dry matter by weight difference (AOAC 925.23), ash by incineration (AOAC 945.46), protein content by determination of total nitrogen by the Kjeldahl method (model Pro-Nitro S, Selecta, Spain) with a conversion factor of 6.25 (AOAC 991.22), total dietary fiber content (AOAC 985.29), fat content by Soxhlet extraction (model SZC-D, Shanghai QianJian Instrument Co. Ltd, China) (AOAC 945.39), and carbohydrate by difference.

\section{Quality evaluation of bread}

To evaluate the effects of okara substitution on bread formulations, the following studies were performed:

Loaf volume of the bread: Loaf volume was measured by small seeds displacement method. ${ }^{10}$ A container was used to measure the volume using small grains. Flax seeds were poured into the container of known volume until the bottom was covered. The loaf was placed inside the container which was then filled to the top with more seeds. The extra flax seeds, which equal the loaf volume, were measured in a graduated cylinder. The specific volume of the loaf was calculated using the following equation:

$$
S V\left(\mathrm{~cm}^{3} / \mathrm{g}\right)=\frac{\text { laofvolumeofbread }}{\text { weightofbread }}
$$

Crust and crumb color of bread (CIELab system): The chromatic characteristics of the bread crust and crumb were determined using a HunterLab colorimeter, model Mini Scan EZ (HunterLab, USA) which was provided with the software. Colour values $\left(\mathrm{L}^{*}, \mathrm{a}^{*}\right.$ and $\left.\mathrm{b}^{*}\right)$ for the control and enhanced bread formulations were recorded, each the average of four measurements at different points in the bread crumb and crust to ensure the reproducibility. $\mathrm{L}^{*}$ is the lightness variable from 100 (white) to zero (black), whilst $\mathrm{a}^{*}$ and $\mathrm{b}^{*}$ are chromaticity, + redness/greenness and+yellowness/blueness, respectively. ${ }^{11,12}$ The color of all breads (crust and crumb) was measured $1 \mathrm{~h}$ after baking. An average of four measurements for $L^{*}, a^{*}$ and $b^{*}$ values were recorded. ${ }^{13}$ Mean values of at least 3 breads were taken for statistical purposes.

Image texture analysis: At macroscopic level, two phases can be identified in bread structure: a solid (wall material) and a gaseous (air cell) one, which are partially connected. So, the nature of their connectivity, their size, uniformity and fraction area determines the structure, and consequently, the mechanical properties of the bread. Therefore, raw materials determine the structure of the bread. ${ }^{14}$ Slices from the center of each bread were scanned with a digital camera. Analysis was performed independently for each image from a sub-image area of $4 \times 4 \mathrm{~cm}$ from the center on each bread slice. The images were analyzed with Image-J $1.47 \mathrm{v}$ (USA). The color image was converted to 8-bits image and was analyzed in a grey scale $(0$ black, 255 white). The image selected was segmented by a grey-value to create a binary image by the algorithm Iso-Data. ${ }^{15}$ From these analyses, the total number and mean size of alveolus and the area factor were obtained. Three slices from the center of each bread loaf were analyzed in each case.

Texture profile analysis (TPA): The mechanical properties of bread samples were measured using a Brookfield texture Pro CT analyzer, (USA). A double compression test was performed with a
$25 \%$ compression with a $38 \mathrm{~mm}$ diameter cylindrical probe and a load cell of $25 \mathrm{~N}$ at a test-speed of $1 \mathrm{~mm} / \mathrm{s}$ and $10 \mathrm{~mm}$ of distance. Breads were cut into $2 \mathrm{~cm}$ thick slices. Tests were conducted after 1day in the central part of the slice. The parameters obtained from the curves were hardness $(\mathrm{N})$, consistency (N.s) and cohesiveness. ${ }^{16}$

\section{Scanning electron microscopy}

The microstructure of breads was analyzed by scanning electron microscopy (SEM, LEO1450VP, Zeiss, Germany). The samples were mounted on double-sided adhesive carbon on aluminum sample holders. The micrographics were determined under VP mode (variable pressure), using 200X magnifications. The low vacuum mode of SEM is a special type, where the chamber can be maintained at low vacuum at $70 \mathrm{~Pa}$, while that the column remains under vacuum. In this way, it is possible to observe biologically sensitive samples without dehydrating or metalizing with gold..$^{17}$

\section{Sensory analyses of breads}

Sensory evaluation tests were performed on bread samples by 80 untrained panel members. The sensory analyses consisted of a comparison test (preference) between the samples which were coded with three-digit numbers and were presented in a randomized order. Apples were provided between samples to cleanse the palate. Then, a statistical analysis was performed using the Turkey-Krumer test, which determines whether the sums of the total orders for each sample di $\square$ er significantly. ${ }^{18}$

\section{Statistical analysis}

Results are expressed as means with standard deviations of analysis performed in triplicate. One-way analysis of variance and Tukey's test were used to establish the significance of differences among mean values at $\mathrm{p} \leq 0.05$. The statistical analyses were performed using GraphPad InStat Software Inc.

\section{Results and discussion}

\section{Drying of okara}

From the drying curves it was possible to estimate the time needed to obtain flours with the characteristics established by CAA. ${ }^{19}$ Figure 1 shows the moisture content of okara during the drying process using a microwave oven. Initially the surface of the okara was very humid, proved by the existence of a continue water film. The film was constituted by free water without mass transfer resistance. The fact that fresh okara has a high moisture level ( $\square 80 \%)$ facilitated the penetration of electromagnetic radiation through the polar molecules, allowing an almost instantaneous warming in the totality of the sample. ${ }^{8}$ Starting at time zero, the free water content corresponds to point A. At the beginning of the drying process, the solid is at a lower temperature than it will be at the end, and the evaporation rate is increasing. At point $\mathrm{B}$, the temperature reaches an average value of $91^{\circ} \mathrm{C}$ (near the boiling point) and evaporation begins to be maximum. It is observed in the Figure 1(A) that the segment BC is a straight line with maximum slope. The drying rate becomes constant; it is represented in the section $\mathrm{BC}$. At point $\mathrm{C}$, in both figures, the drying speed begins to decrease until reaching the point $\mathrm{D}$. The $\mathrm{CD}$ segment represents the period of decreasing speed. In this stage, the water was removed. The solid material increased the temperature and the drying rate decreased rapidly tending to become zero, as the final moisture was approached. ${ }^{20}$ 

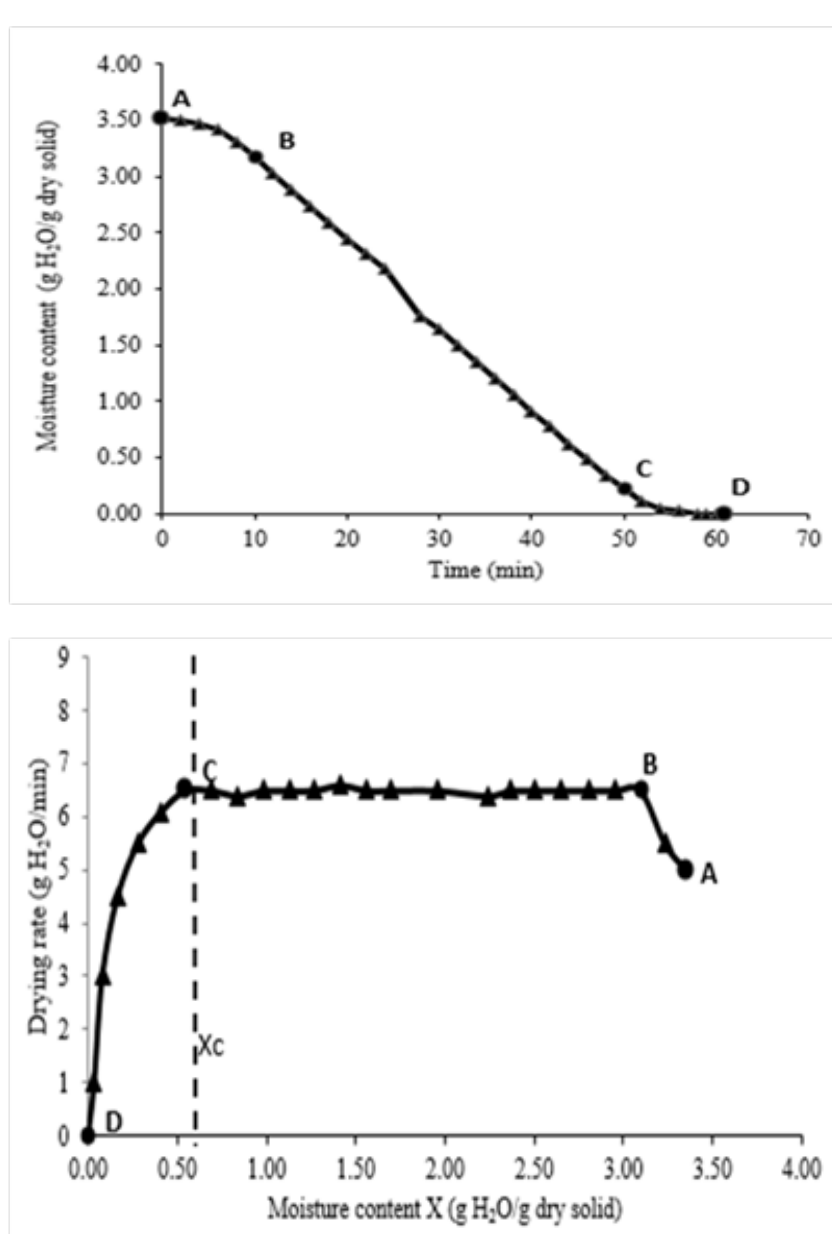

Figure I A) Moisture content of okara during the drying process using a microwave oven.

B) Drying rate $\left(\mathrm{g} \mathrm{H}_{2} \mathrm{O} / \mathrm{min}\right)$ vs Moisture content ( $\mathrm{g} \mathrm{H}_{2} \mathrm{O} / \mathrm{g}$ dry solid).

\section{Physicochemical analysis}

The okara quality was evaluated before being incorporated into the bread. The proximate composition of okara flour was determined in the laboratory. The protein content was $34.61 \pm 1.49 \%$; fiber $20.37 \pm 1.20 \%$; fat $19.10 \pm 4.67 \%$; ash $3.44 \pm 0.41 \%$; moisture $1.38 \pm 0.14 \%$; and total carbohydrates $21.11 \pm 1.58 \%$. Our results were in agreement with ${ }^{21}$ and. ${ }^{22}$ However, it is a common knowledge that the chemical composition of okara will depend on the procedure followed to obtain it. The results of chemical analyses performed on breads are summarized in Table 1. As expected, the protein and fiber content increased with the level of substitution of okara flour. The replacement with okara flour produced a decrease in carbohydrates and an increase in ash content. The moisture content was not significantly a $\square$ ected, however, since protein and fiber has hygroscopic nature, the samples retained more moisture during the baking cycle. ${ }^{23,24}$

\section{Quality evaluation of bread}

Specific volume of breads: The specific volume for the different experimental bread types are shown in Table 2. The specific volume, which is the ratio between the volume and weight, has been adopted in the literature as the most reliable measure of bread. ${ }^{25}$ The result shown that, the higher the replacement of okara, the lower the specific volume. This behavior could be due to the dilution of gluten, or to the interaction between gluten and fiber. This phenomenon could be also a result of the fiber weakening or crippling dough structure and reducing $\mathrm{CO}_{2}$ gas retention. ${ }^{6}$ Moreover, the absence of gluten in okara flours had a great influence on the bread' rheological properties.

Crust and crumb color of breads: The values relating to the color analysis of the crumb and the crust of the experimental bread samples are listed in Table 3. Such analyses have shown considerable differences regarding $\mathrm{L}^{*}, \mathrm{a}^{*}$ and $\mathrm{b}^{*}$ between samples with and without okara. The results showed that when the color crust and crumb of breads were evaluated across the space CIELAB, darkening was verified due to the incorporation of okara. The increase in color values may be attributed to interaction of protein and sugar at baking temperatures resulting in a higher degree of Maillard reaction. This result indicates a browning of the crust and crumb with the incorporation of okara, demonstrating a marked reddish-dun color and an increased yellowness.

Texture profile analysis: Breads enriched with okara presented greater firmness, cohesion and chewability than control sample. There are different factors that (Table 4) increase the viscosity of the dough such as: dilution of the gluten's matrix, the formation of defects in gluten due to soybean's fiber, the exchange of disulfide bonds between soy's proteins and gluten's proteins. ${ }^{26}$ Regarding to adherence, samples did not showed statistically significant difference. In general, the incorporation of saccharides and proteins in bread formulations increased the hardness of the samples. ${ }^{12}$ Results were similar to values reported by Roccia Ruffinengo Paola. ${ }^{27}$

\section{Scanning electron microscopy}

At macroscopic level, two phases can be identified in bread structure: a solid (wall material) and a gaseous (air cell) one, which are partially connected. So, the nature of their connectivity, their size, uniformity and fraction area determines the structure, and consequently, the mechanical properties of the bread. Therefore, raw materials determine the structure of the bread. ${ }^{14}$ Electron micrographs were made in order to establish the relationships between the microstructure of breads and their composition. In the Figure 2 images obtained for the breads with different concentrations of okara are shown. The micrographs of breads elaborated with okara show a different structure compare with the control sample. This is possibly due to the fibers and proteins present in the okara flour, which might interfere in the structure of the matrix, diminishing the gas retention capacity in the dough. Excess amounts of insoluble dietary fiber had an adverse effect on the formation of gluten network and reduced the quality of bread due to gluten dilution effect or gluten -fiber interaction. $^{6}$

Image texture analysis : Image analysis was performed on each scanned bread slice to provide a more detailed view of the bread texture. It can be observed in Table 5 that the number of air cell in the range of sizes of $0.5-4 \mathrm{~mm}^{2}$ (average size $1.4 \mathrm{~mm}^{2}$ ) decreases when increase the concentration of okara. Control and 5-O samples presented a structure of the crumb with a greater number of air cell than the other formulations, inducing a more uniform distribution of them and a more aerated crumb. In the range of $4-100 \mathrm{~mm}^{2}$ (average size $13 \mathrm{~mm}^{2}$ ) the number of air cell increases with the content of okara and the shape factor value approaches to 0 , it indicate an increasingly elongated form, which represent a collapse in the structure of the crumb with the consequent compaction of it. 


\section{Sensory characteristics of breads enriched with okara}

The effects of okara addition on the sensory characteristics of breads are presented in Figure 3. The sensory analysis was carried out with the 3 formulations of bread enriched with okara, in order to determine sensory attributes such as: color, manual texture, taste and

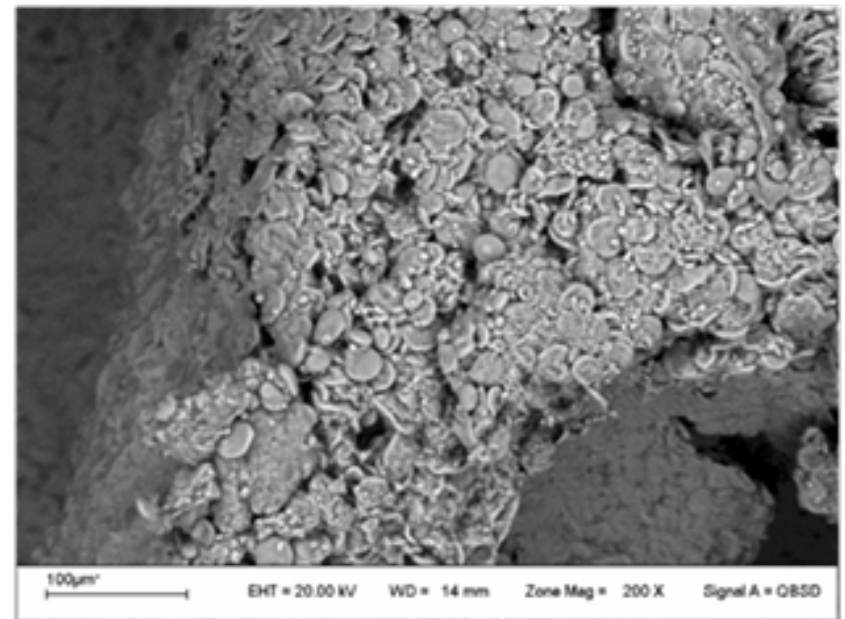

(A) Control Sample

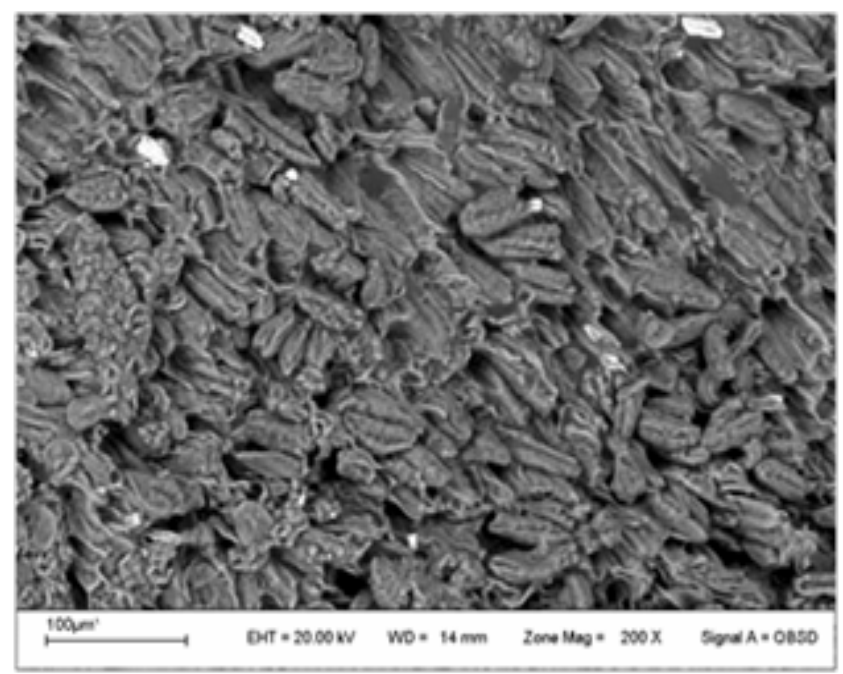

(C) 7.5-O overall preference. It was concluded from the multiple comparisons test that the color of the 5-O and the manual texture of 7.5-O were statistically preferred. While flavor and overall preference attributes did not present significant difference in sample ordering. It is important to highlight that all the formulations were accepted by the panelists, and the bean flavor was not perceived by them.

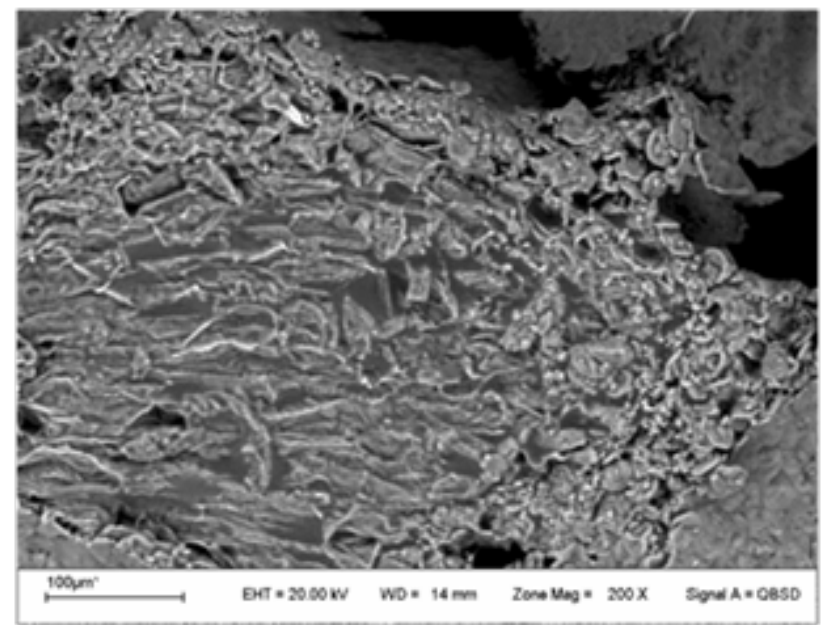

(B) $5-0$

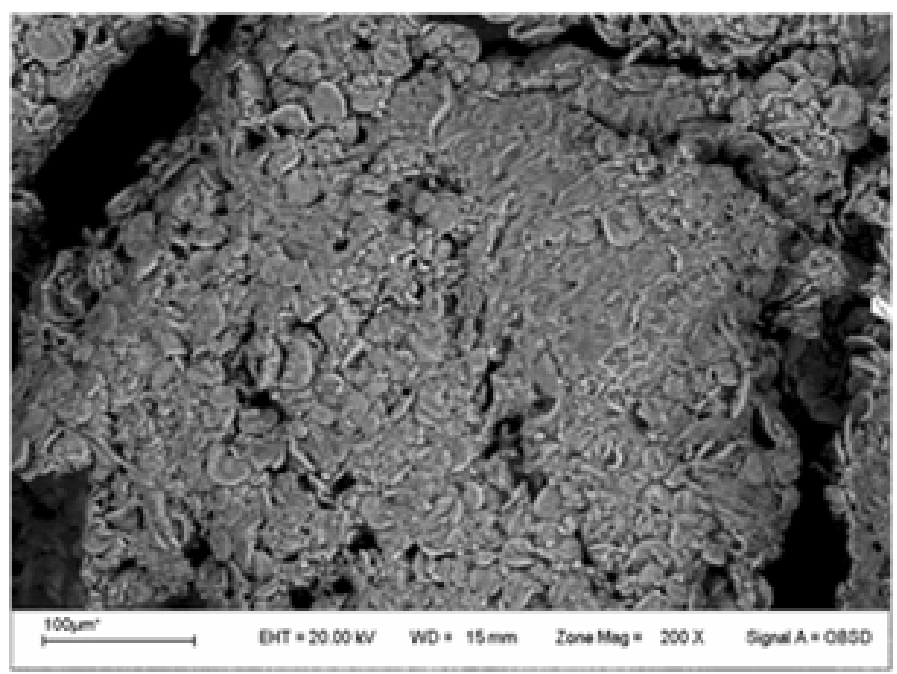

(D) $10-\mathrm{O}$

Figure 2 Scanning electron microscopy (SEM) of bread matrix. Magnification: 200x.

A) Control.

B) $5-\mathrm{O}$.

C) $7.5-0$.

D) $10-0$. 


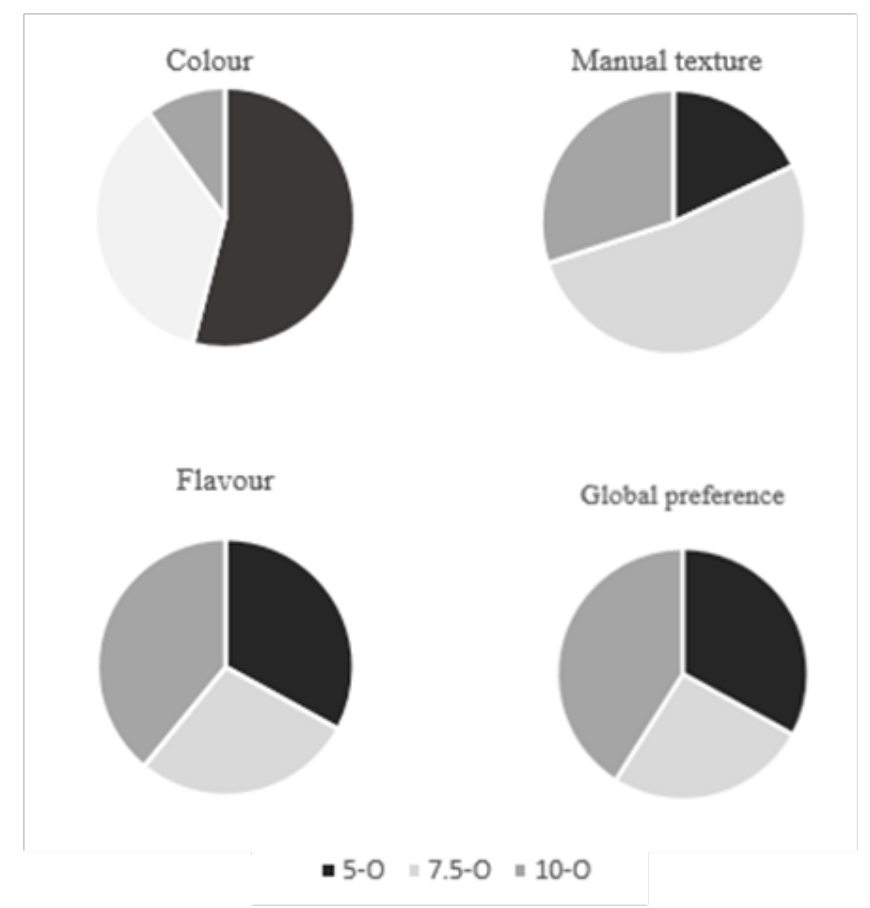

Figure 3 Sensory analysis was carried out with the 3 formulations of bread enriched with okara.

Table I Proximate composition of breads with different concentration of okara (O)

\begin{tabular}{lllllll}
\hline Sample & Protein $(\mathbf{g} / \mathbf{1 0 0 g})$ & Fat $(\mathbf{g} / \mathbf{1 0 0 g})$ & Ash $(\mathbf{g} / \mathbf{1 0 0 g})$ & Moisture $(\mathbf{g} / \mathbf{1 0 0 g})$ & Carbohydrates $(\mathbf{g} / \mathbf{1 0 0 g})$ & Fiber $(\mathbf{g} / \mathbf{1 0 0 g})$ \\
\hline Control & $7.45 \pm 0.25^{\mathrm{a}}$ & $3.95 \pm 0.30^{\mathrm{a}}$ & $1.35 \pm 0.10^{\mathrm{a}}$ & $49.35 \pm 3.80^{\mathrm{a}}$ & $37.89 \pm 3.70^{\mathrm{a}}$ & $0.012 \pm 0.006^{\mathrm{a}}$ \\
$5-\mathrm{O}$ & $8.85 \pm 0.37^{\mathrm{b}}$ & $5.28 \pm 0.20^{\mathrm{b}}$ & $1.67 \pm 0.08^{\mathrm{a}}$ & $51.14 \pm 5.50^{\mathrm{a}}$ & $32.3 \pm 5.70^{\mathrm{a} . \mathrm{b}}$ & $0.74 \pm 0.100^{\mathrm{b}}$ \\
$7.5-O$ & $9.80 \pm 0.37^{\mathrm{c}}$ & $6.76 \pm 0.50^{\mathrm{c}}$ & $1.63 \pm 0.10^{\mathrm{a}}$ & $53.59 \pm 3.50^{\mathrm{a}}$ & $26.85 \pm 4.20^{\mathrm{a} . \mathrm{b}}$ & $1.31 \pm 0.170^{\mathrm{c}}$ \\
$10-\mathrm{O}$ & $9.98 \pm 0.25^{\mathrm{c}}$ & $6.84 \pm 0.60^{\mathrm{c}}$ & $1.74 \pm 0.09^{\mathrm{a}}$ & $54.92 \pm 3.10^{\mathrm{a}}$ & $24.58 \pm 3.80^{\mathrm{b}}$ & $1.87 \pm 0.200^{\mathrm{d}}$ \\
\hline
\end{tabular}

Means followed by different letters in the same row are significantly different $(P<0.05)$

Table 2 Specific Volume (SV) of breads

\begin{tabular}{ll}
\hline Sample & SV $\left(\mathbf{c m}^{3} / \mathbf{g}\right)$ \\
\hline Control & $2.95 \pm 0.98^{\mathrm{a}}$ \\
$5-0$ & $2.78 \pm 0.77^{\mathrm{a}}$ \\
$7.5-0$ & $2.52 \pm 0.27^{\mathrm{a}}$ \\
$10-0$ & $2.06 \pm 0.68^{\mathrm{a}}$ \\
\hline
\end{tabular}

Means followed by different letters in the same row are significantly different $(P<0.05)$.

Table 3 Crust and crumb color of breads

\begin{tabular}{lllllll}
\hline Crust & & \multicolumn{5}{l}{ Crumb } \\
\hline Sample & $\mathbf{L}^{*}$ & $\mathbf{a}^{*}$ & $\mathbf{b}^{*}$ & $\mathbf{L}^{*}$ & $\mathbf{a}^{*}$ & $\mathbf{b}^{*}$ \\
\hline Control & $63.08 \pm 0.5^{\mathrm{a}}$ & $9.53 \pm 0.2^{\mathrm{a}}$ & $35.96 \pm 0.01^{\mathrm{a}}$ & $70.09 \pm 0.4^{\mathrm{a}}$ & $0.81 \pm 0.2^{\mathrm{a}}$ & $13.95 \pm 0.1^{\mathrm{a}}$ \\
$5-\mathrm{O}$ & $52.82 \pm 1.9^{\mathrm{b}}$ & $15.53 \pm 0.2^{\mathrm{b} . \mathrm{d}}$ & $27.72 \pm 0.06^{\mathrm{b}}$ & $67.88 \pm 0.5^{\text {a.b }}$ & $2.07 \pm 0.1^{\mathrm{b}}$ & $18.8 \pm 2.4^{\mathrm{b}}$ \\
$7.5-\mathrm{O}$ & $47.65 \pm 4.8^{\mathrm{b}}$ & $13.39 \pm 1.2^{\text {c.d }}$ & $27.68 \pm 0.08^{\mathrm{b}}$ & $68.03 \pm 1.5^{\mathrm{a}}$ & $2.95 \pm 0.09^{\mathrm{c}}$ & $18.94 \pm 1.1^{\mathrm{b}}$ \\
$10-\mathrm{O}$ & $46.47 \pm 3.5^{\mathrm{b}}$ & $14.17 \pm 0.6^{\mathrm{d}}$ & $27.43 \pm 0.03^{\mathrm{b}}$ & $64.82 \pm 1.8^{\mathrm{b}}$ & $3.8 \pm 0.2^{\mathrm{d}}$ & $20.23 \pm 1.0^{\mathrm{b}}$ \\
\hline
\end{tabular}

Means followed by different letters in the same row are significantly different $(P<0.05)$. 
Table 4 Texture profile analysis of breads

\begin{tabular}{lllll}
\hline Sample & Firmness $(\mathbf{g})$ & Adherence $(\mathbf{m j})$ & Chewability $(\mathbf{m j})$ & Cohesion $(\mathbf{m j})$ \\
\hline Control & $579 \pm 166^{\mathrm{a}}$ & $0.02 \pm 0.03^{\mathrm{a}}$ & $43.8 \pm 14^{\mathrm{a}}$ & $0.28 \pm 0.01^{\mathrm{a}}$ \\
$5-\mathrm{O}$ & $686.6 \pm 49^{\mathrm{a}}$ & $0 \pm 0^{\mathrm{a}}$ & $49.7 \pm 3.5^{\mathrm{a}}$ & $0.32 \pm 0.01^{\mathrm{ab}}$ \\
$7.5-\mathrm{O}$ & 688.7 & $0 \pm 0^{\mathrm{a}}$ & $49.8 \pm 2.8^{\mathrm{a}}$ & $0.36 \pm 0.04^{\mathrm{b}}$ \\
$10-\mathrm{O}$ & $691.8 \pm 64^{\mathrm{a}}$ & $0.02 \pm 0.03^{\mathrm{a}}$ & $50.3 \pm 4.5^{\mathrm{a}}$ & $0.37 \pm 0.03^{\mathrm{b}}$ \\
\hline
\end{tabular}

Means followed by different letters in the same row are significantly different $(P<0.05)$.

Table 5 Number of air cell in different ranges and shape factor

\begin{tabular}{|c|c|c|c|c|c|c|}
\hline & \multicolumn{2}{|c|}{$\mathrm{N}^{\circ}$ air cell $(\mathrm{N})$} & \multicolumn{2}{|c|}{ Mean size of air cell } & \multicolumn{2}{|l|}{ Shape factor } \\
\hline & $0,5-4 \mathrm{~mm}^{2}$ & $4-100 \mathrm{~mm}^{2}$ & $0,5-4 \mathrm{~mm}^{2}$ & $4-100 \mathrm{~mm}^{2}$ & $0,5-4$ mm$^{2}$ & $4-100 \mathrm{~mm}^{2}$ \\
\hline Control & 44 & 11 & 1.436 & 12.825 & 0.202 & 0.093 \\
\hline $5-\mathrm{O}$ & 41 & 12 & 1.315 & 13.655 & 0.197 & 0.083 \\
\hline $7.5-\mathrm{O}$ & 39 & 13 & 1.311 & 12.489 & 0.212 & 0.08 \\
\hline $10-\mathrm{O}$ & 34 & 16 & 1.529 & 13.052 & 0.208 & 0.064 \\
\hline
\end{tabular}

Means followed by different letters in the same row are significantly different $(P<0.05)$.

\section{Conclusion}

Okara is a rich source of nutrients that could be utilized in bakery industry. The results obtained in this study indicated that the combination of wheat flour and okara flour allowed the development of bread with enhanced functional properties. Fresh okara was dried by microwave. It was possible to obtain a dehydrated product with $0.5 \%$ moisture content in 61 minutes. The physicochemical analyses revealed that the principal nutritional advantage of bread samples elaborated with okara flour and wheat flour is its high fiber and protein content. According to the physical properties, the incorporation of okara in the formula reduced the size of the product, giving rise to harder and darker breads. Also, an increase in okara content decreased the specific volume of bread, this phenomenon could be a result of the fiber weakening or crippling dough structure and reducing $\mathrm{CO}_{2}$ gas retention. Regarding to the structure of the crumb: the quantity of alveoli increases when okara content is higher and the elongated forms predominate, as consequence, a more compact crumb was obtained, as was corroborated by electronic microscopy. It was observed that bread enriched with okara presented higher firmness, cohesion and chewability compare with control sample. However, the samples exhibited great acceptable sensory characteristics among consumer panel members. Regarding to flavor and global preference attributes samples did not present significant difference. It is important to highlight that all the formulations were accepted by the panelists, and bean flavor was not perceived. Okara could be utilized to improve the nutritional quality of breads. The okara substitution in bakery industry would be beneficial in reducing the usage of wheat flour and also overcome the waste disposal problem prevailing in the soymilk industries.

\section{Acknowledgements}

Financial support provided by the SCyT, UNSL (Project 2-3114), also fellowships of Eng. Ostermann Porcel of CONICET (Argentina) are gratefully acknowledged.

\section{Conflicts of interest}

The author declares no conflict of interest.

\section{References}

1. Wickramarathna GL, Arampath PC. Utilization of okara in bread making. Ceylon Journal of Science. 2003;31:29-33.

2. Fei L, Zhenkun C, Yang L, Bo L. The effect of okara on the qualities of noodle and steamed bread. Advance Journal of Food Science and Technology. 2003;(7):960-968.

3. Schved F, Hassidov B. Okara, a natural food ingredient for new product development of foodstuffs. Dietary fibres \& pre/probiotics. 2010;21(2).

4. Fei L, Zhenkun C, Yang L, et al. Okara dietary fiber and hypoglycemic effect of okara foods. Bioactive Carbohydrates and Dietary Fibre. 2013;2:126-132.

5. Sengupta S, Chakraborty M, Bhowal J, et al. Study on the effects of drying process on the composition and quality of wet okara. International Journal of Science Environment and Technology. 2012;1(4):319-330.

6. Fendri L, Chaari F, Maaloul M, et al. Wheat bread enrichment by pea and broad bean pods fibers: effect on dough rheology and bread quality. $L W T$ Food Science and Technology. 2016;73:584-591.

7. Ostermann Porcel MV, Quiroga Panelo N, Rinaldoni AN, et al Incorporation of Okara into gluten-free cookies with high quality and nutritional value. Journal of Food Quality. 2017;2017:8.

8. Ostermann Porcel MV, Rinaldoni AN, Rodriguez Furlán LT, et al. Quality assessment of dried okara as source of production of gluten-free flour. Journal of the science of food and agriculture. 2016;97(9):2934-2941.

9. AOAC. Official Methods of Analysis. 16th ed. Association of official analytical chemists, Arlington, USA: VA; 1995

10. American association of cereal chemists (AACC). Approved Methods of the American Association of Cereal Chemists. 9th ed. Eagan, Minn, USA: American association of cereal chemists (AACC); 2000

11. Morales FJ, Van Boeckel MAJS. A study on advanced Maillard reaction in heated casein/sugar solutions: Colour formation. International Dairy Journal. 1999;8:907-915.

12. Skendi A, Biliaderis CG, Papageorgiou M, et al. Effects of two barley b-glucan isolates on wheat flour dough and bread properties. Food Chemistry. 2010;119:1159-1167.

13. Ma CY, Liu WS, Kwok KC, et al. Isolation and characterization of 
proteins from soymilk residue (okara). Food Research International. 1997;29(8):799-805.

14. Scanlon MG, Zghal MC. Bread properties and crumb structure. Food Research International. 2001;34:841-864.

15. Raband WS. Image J, U. S. National Institute of Health, Bethesda, Maryland, USA; 2009.

16. Civille GV, Szczesniak AS. Guidelines to training a texture profile panel. Journal of texture studies. 1973;4(2):204-223.

17. Sammons R, Marquis P. Application of the low vacuum scanning electron microscope to the study of biomaterials and mammalian cells. Biomaterials. 1997;18(1):81-86.

18. Meilgaard M, Civille G, Carr B. Sensory Evaluation Techniques. 4th ed New Jersey, NJ, USA: CRC Press; 2006.

19. CAA, Código Alimentario Argentino. Administración Nacional de Alimentos, Medicamentos y Tecnología Médica, Capítulo IX.

20. Geankoplis CJ. Procesos de transporte y operaciones unitarias. 3rd ed México: Compañia editorial Continental; 1998. p. 596-599.
21. Ma CY, Liu WS, Kwok KC, et al. Isolation and characterization of proteins from soymilk residue (okara). Food Research International. 1996;29(8):799-805.

22. Vishwanathan $\mathrm{KH}$, Singh V, Subramanian R. Influence of particle size on protein extractability from soybean and okara. Journal of Food Engineering. 2011;102(3):240-246.

23. Nilufer Erdil D, Serventi L, Boyacioglu D, et al. Effect of soy milk powder addition on staling of soy bread. Food Chemistry. 2012. p. 1132-1138.

24. Vittadini E, Vodovotz Y. Changes in physicochemical properties of wheat and soy-containing breads during storage as studied by thermal analyses. Journal of food science. 2003;68(6):2022-2077.

25. Costantini L, Lukšic L, Molinari R, et al. Development of gluten-free bread using tartary buckwheat and chia flour rich in flavonoids and omega-3 fatty acids as ingredients. Food Chemistry. 2014;165:232-240.

26. MohamedAA, Rayas Duarte P, et al. Low carbohydrates bread: Formulation, processing and sensory quality. Food Chemistry. 2006;99(4):686-696.

27. Roccia Ruffinengo Paola. Uso de enzimas y oxidantes en productos de panificación fortificados. Universidad Nacionald; 2011. 256 p. 